\title{
College wage premiums and skills: a cross-country analysis
}

Citation for published version (APA):

van der Velden, R., \& Bijlsma, I. (2016). College wage premiums and skills: a cross-country analysis. Oxford Review of Economic Policy, 32(4), 497-513. https://doi.org/10.1093/oxrep/grw027

Document status and date:

Published: 01/01/2016

DOI:

10.1093/oxrep/grw027

Document Version:

Publisher's PDF, also known as Version of record

Document license:

Taverne

Please check the document version of this publication:

- A submitted manuscript is the version of the article upon submission and before peer-review. There can be important differences between the submitted version and the official published version of record.

People interested in the research are advised to contact the author for the final version of the publication, or visit the DOI to the publisher's website.

- The final author version and the galley proof are versions of the publication after peer review.

- The final published version features the final layout of the paper including the volume, issue and page numbers.

Link to publication

\footnotetext{
General rights rights.

- You may freely distribute the URL identifying the publication in the public portal. please follow below link for the End User Agreement:

www.umlib.nl/taverne-license

Take down policy

If you believe that this document breaches copyright please contact us at:

repository@maastrichtuniversity.nl

providing details and we will investigate your claim.
}

Copyright and moral rights for the publications made accessible in the public portal are retained by the authors and/or other copyright owners and it is a condition of accessing publications that users recognise and abide by the legal requirements associated with these

- Users may download and print one copy of any publication from the public portal for the purpose of private study or research.

- You may not further distribute the material or use it for any profit-making activity or commercial gain

If the publication is distributed under the terms of Article $25 \mathrm{fa}$ of the Dutch Copyright Act, indicated by the "Taverne" license above, 
Oxford Review of Economic Policy, Volume 32, Number 4, 2016, pp. 497-513

\title{
College wage premiums and skills: a cross-country analysis
}

\section{Rolf van der Velden* and Ineke Bijlsma**}

\begin{abstract}
Workers with a college degree earn substantially more than workers with no such degree. Using recent data from 22 OECD (Organization for Economic Cooperation and Development) countries, we estimate this college wage premium at 28 per cent for male full-time working employees, on average, ranging from 18 per cent in Sweden to 50 per cent in the Slovak Republic. This premium is largely explained by the higher skill levels of graduates from higher education combined with their use of these skills at work, as well as the match with job requirements for this skill proficiency and skill use. We find no effect of labour market institutions (e.g. the employment protection legislation or the coverage rate) on cross-country differences in the college wage premium. However, we find that cross-country variation in this premium is related to the relative supply of higher educated workers. Moreover, we find evidence that cross-country differences in the college wage premium are related to the degree to which educational credentials signal skills.
\end{abstract}

Keywords: college wage premium, skills, skill use, (mis)match, relative supply, signalling, institutions JEL classification: I26, J24

\section{Introduction}

Workers with a college degree earn substantially more than their peers who have no such degree, the so-called college wage premium (James, 2011; Crivellaro, 2014). However, the large increase in higher education enrolment has cast doubt on the sustainability of this college wage premium (Thurow, 1975; Freeman, 1976) and highlighted possible negative effects of overeducation (Bills, 2003). In the public debate, concerns have been expressed about the further expansion of the education system, resulting in growing unemployment rates among graduates, and increasing proportions of graduates unable to find a job for which a college degree is necessary. Even policy-makers who have welcomed the expansion of higher education in the past are now concerned about increasing skill mismatches in the labour market (European Commission, 2013; OECD, 2015).

\footnotetext{
* Research Centre for Education and the Labour Market, Maastricht University, e-mail: r.vandervelden@ maastrichtuniversity.nl (corresponding author)

** Research Centre for Education and the Labour Market, Maastricht University, e-mail: i.bijlsma@ maastrichtuniversity.nl

We thank Christopher Bliss, an anonymous reviewer, and participants in the Oxford Review's editorial seminar on 21 March 2016 for their comments on an earlier version. doi:10.1093/oxrep/grw027

(C) The Authors 2016. Published by Oxford University Press.

For permissions please e-mail: journals.permissions@oup.com
} 
Surprisingly, and despite the sharp increase in higher education enrolment, the college wage premium has not decreased substantially over time. In the United States, there was even an increase in the premium in the 1980s and 1990s. In the United Kingdom, the college wage premium has remained more or less stable in the past two decades, although it seems to have declined since 2002 (Walker and Zhu, 2008). Crivellaro (2014), using data from the EU-SILC (European Survey of Income and Living Conditions) and the ECHP (European Community Household Panel), shows that changes in supply and demand have an effect on the college wage premium. The author shows that an increase in the relative supply of higher educated workers decreases the college wage premium.

The most prominent explanation of possible stability in the college wage premium is that demand for highly skilled workers has increased at the same time. The so-called skill-biased technological change (SBTC) explanation was first formulated by Katz and Murphy (1992), who analyse changes in the US college wage premium over the period 1963-87. Later, Goldin and Katz (2007, p. 1) extended this analysis to 1890-2005 and conclude that in the 'race between education and technology, the strong secular growth in the relative demand for more educated workers combined with fluctuations in the growth of relative supplies go far to explain the long-run evolution of US educational wage differentials'. ${ }^{1}$

A crucial assumption in the SBTC explanation is that skills explain the college wage premium. In other words, the premium for having a college degree is driven by the (on average) higher skill level of graduates. Although this seems plausible, there are alternative explanations. The relative stability of the college wage premium could also be due to institutional factors, such as wage setting mechanisms and labour market regulations. One potential explanation for the differences in the college wage premium between the United States and many European countries is that, in the latter countries, institutional factors play a more dominant role, thus reducing overall wage inequality as well as the relative college wage premium. However, Crivellaro (2014), using data from the EU-SILC and the ECHP shows that changes in supply and demand drive most of the changes in the college wage premium and that institutional factors such as the employment protection legislation (EPL), union density, or minimum wages play no role or just a minor one.

Another alternative explanation is that it is the sorting function of education and not skills that drive the college wage premium (Arrow, 1973; Bills, 2003). In this view, education is merely a machine that sorts students by their innate learning ability rather than equipping them with skills that are directly needed in the labour market. Alternatively, higher education is viewed as a gateway to prestigious jobs (Collins, 1979). Prestigious jobs are rationed and higher education serves as a channel to obtain these jobs. Social capital and networking are, in this view, just as important to gain access to these jobs as acquiring the right kinds of skills. All of these alternative explanations put into question the relation between enrolment in higher education, skill development, and access to well-paid jobs.

It is not easy to directly test these alternative explanations but they can be tested indirectly by looking at the mediating effect of skill levels to explain the relation between college degrees and the wage premium. If this mediating effect is strong, alternative

\footnotetext{
1 As one of the reviewers pointed out, Goldin and Katz (2007) do not control for foreign trade effects, which could specifically decrease the wages for unskilled workers.
} 
explanations (sorting on innate learning abilities, social capital formation during studies) are less convincing. Let us look at the puzzle regarding the effect of increasing enrolment in higher education and the effect this has on student skill development. Many authors assume that the increase in enrolment rates will also have changed the skills composition of the higher educated, since the expansion is likely to come from the least-skilled high school graduates (assuming that the best-skilled high school graduates will already have entered higher education). Grogger and Eide (1995) explore this issue using two sets of panel data and analyse the increase in the college wage premium in the United States during the 1980s. They conclude that skills obtained prior to college had no effect on this change in the wage premium, but that the distribution over college majors changed in favour of fields requiring a high level of analytical skills, such as engineering. These changes in the choice of college major account for onefourth of the increase in the male college wage premium. Walker and Zhu (2008) take a different approach. They analyse UK labour force data during 1994-2006. They show that, despite the huge increase in higher education participation rates, the college wage premium did not change much. However, they find that the college wage premium is not distributed evenly over the entire wage distribution. They show a fall in the college wage premium for men in the bottom quartile of the distribution of unobserved skills. Crivellaro (2014) uses an instrumental variable (IV) approach to assess the causal effect of changes in the supply of graduates. In comparing the ordinary least squares (OLS) and IV results, the author concludes that the OLS results are upward biased and speculates that this could be due to changes in the relative ability of college graduates. Such analyses are frequently hampered by the fact that skills are often not directly measured and, therefore, assumptions have to be made about the underlying mechanism. Levels et al. (2014) open up this black box of the relationship between education, skills, and wages and use data from the newly developed Program for the International Assessment of Adult Competencies (PIAAC) from the OECD (2013a), to explain the effect of educational mismatches on wages. They find that the negative effect of overeducation on wages is largely explained by skills, but the extent to which this is the case differs between countries, and is constrained by labour market institutions. Hanushek et al. (2015) also use PIAAC data to assess the effect of skills on wages. They show that a one standard deviation increase in numeracy ${ }^{2}$ skills is associated with an 18 per cent increase in wages for prime-age workers. However, these returns differ markedly between countries.

Levels et al. (2014) focus on explaining the effects of overeducation on wages and look at the role of skills and labour market institutions. Hanushek et al. (2015) focus on the effect of skills on wages and control for school attainment to make their case. We take a different approach and determine how the college wage premium is related to skills and their use, as well as differences in the match between required and acquired skills. Although the relation between the college wage premium and skills is intuitively appealing, it has not been directly tested from a cross-country perspective with good

2 It is important to note that numeracy skills are defined as a key skill that affects many outcomes in life $(\mathrm{OECD}, 2013 a)$. Numeracy is defined as 'the ability to access, use, interpret, and communicate mathematical information and ideas in order to engage in and manage the mathematical demands of a range of situations in adult life' (OECD, 2013a, p. 59). Numeracy has been shown to be the strongest predictor of wages of all assessed key skills (Levels et al., 2014; Hanushek et al., 2015). 
estimates of skill (mis)matches. Neither has the negative relation between high college participation rates and the quality (skills) of graduates been explored. We elaborate on this using the PIAAC data. This data set provides a good opportunity to examine college wage premiums and the extent to which they are explained by skills. Since these are cross-sectional data, we will not be able to look at changes over time, nor will we be using an IV approach to address the causality between schooling variables, skills, and wages. In that sense, the analysis is predominantly explorative and descriptive. Its contribution lies in the fact that we shed light on the nature of the college wage premium, how it varies across countries, whether the premiums are related to differences in crosscountry differences in skill profiles, the use of these skills and skill (mis)matches, and whether the cross-country variation in these premiums is related to the relative supply of higher educated, to the reliability of educational credentials, or to labour market institutions such as the EPL or the coverage rate.

The results show that the college wage premium is explained not only by the skills, but also by the extent to which these skills are actually used on the job and the extent to which there is a match between job requirements (in terms of skill proficiency level and skill use) and the actual proficiency level and skill use of the job holder. This effect is stronger for the case of workers in the private sector, where the college wage premium drops by 72 per cent after controlling for these factors. For workers in the public sector, this drop in the college wage premium is slightly less, 45 per cent, indicating that institutional factors also play a role in determining the college wage premium in the public sector. We show that cross-country differences in the college wage premium are clearly related to the relative supply of the higher educated. Controlling for skills, we find the relative supply of the higher educated in the relevant workforce has a negative effect on the college wage premium. We also show that cross-country differences in the college wage premium are somewhat related to how strongly educational credentials signal skills (Arrow, 1973; Spence, 1973). In countries where this signal is strong, the college wage premium is highest. This is even the case when we control for skills at the individual level, suggesting that this signalling value also increases the wage premium for the college educated who lack such skills. We find no effect of labour market institutions such as the EPL or the coverage rate on cross-country differences in the college wage premium.

The remainder of the paper is organized as follows. Section II describes the data. Section III develops the model and underlying hypotheses. Section IV presents the results and section $\mathrm{V}$ concludes the paper.

\section{Data}

We use the PIAAC data set (OECD, 2013b), which assesses the proficiency of the adult population in key information-processing skills in OECD countries. The survey is designed to be cross-culturally and cross-nationally valid. The original data set comprises 24 countries and about 166,000 respondents. The national samples are representative samples of non-institutionalized persons aged 16 to 65. Most countries have around 5,000 respondents in the sample, with the exception of Canada, which has more than 27,000 respondents. We excluded Australia from this data set because of data 
protection rules, and the Russian Federation because we are not sure about the data quality. We took a random sample of 20 per cent of the Canadian sample to avoid its overrepresentation in the total data set.

The PIAAC survey comprises a combination of computer-based assessment and-for those who were unable or unwilling to take the computer-based testpaper and pencil data collection strategies to assess the proficiency of respondents in three key information-processing skills: numeracy, literacy, and problem solving in technology-rich environments. We focus only on numeracy. Note, however, that the PIAAC test of numeracy is more than simply reflecting school-based knowledge of arithmetic and mathematics. It is regarded as a key information-processing skill in managing demands in a range of situations in adult life that require a mathematical understanding. As such, it is a key predictor of many outcomes, such as income, social status, civic participation, and health (OECD, 2013a; Levels et al., 2014). Adaptive testing and item response techniques are used to calculate 10 plausible values. Together, these plausible values on numeracy provide an unbiased estimate of the 'real' score if the respondent had taken all the numeracy-related items (OECD, $2013 b$ ). The numeracy scale ranges from zero to 500, with an OECD international average of 273 .

For the analysis, we selected male full-time working employees to avoid different wage-setting regimes for part-timers and women. ${ }^{3}$ In addition, the relation between skills and earnings for the self-employed is quite different from that for employees. Full-time is defined as working 32 hours or more per week. We only selected respondents for whom we have valid information on skill proficiency, skill use, occupation, and hourly wages.

The dependent variable is the logarithm of hourly wages. ${ }^{4}$ Wages are trimmed, leaving out the first and 99th percentiles of the respondents in each country.

As predictors, we use the respondent's highest level of completed education, distinguishing higher educated (International Standard Classification of Education (ISCED) 5 and 6), medium educated (ISCED 3 and 4), and low educated (ISCED 1 and 2). In all models, we further control for age and age squared. We assess the role of skills in explaining the college wage premium in three different ways. First, we use the respondent's proficiency level in numeracy. We use the average of 10 plausible values standardized with mean zero and standard deviation one.

Second, we use a concept called proficient skill use, developed by van der Velden and Bijlsma (2015). The basic rationale of these authors is to integrate skill proficiency and skill use into a new concept, proficient skill use. Proficient skill use is defined as a multiplicative function of skill proficiency in a domain and the use of skills in that domain. The intuitive understanding of this concept is that a skill can have no effect if it is not being used and, vice versa, using a skill can have only little impact if the proficiency level is low. For further information on the development and rationale of this concept, see van der Velden and Bijlsma (2015).

Third, van der Velden and Bijlsma (2015) also developed skill match indicators using this concept of proficient skill use. We follow them and distinguish five relevant situations:

3 As a robustness check, we also ran the same analyses for full-time working women. These results are qualitatively the same. The results are available upon request.

${ }^{4}$ Hourly wages are all adjusted for cross-national differences by a purchasing power parity conversion. 
- a respondent has the required skills and uses these as required,

- a respondent has more skills than required but uses these as required,

- a respondent has fewer skills than required but uses these as required,

- a respondent has the required skills but uses these more than required,

- a respondent has the required skills but uses these less than required.

Each of these situations leads to different returns of proficient skill use. The returns are higher for skill proficiency level than for skill use and higher when skills are required than when they are not. To estimate average skill proficiency and skill use levels for each International Standard Classification of Occupations (ISCO) two-digit occupation in the different countries, the authors follow the calculations of Allen and Bijlsma (2015), who developed robust occupational skill profiles for each country and each two-digit ISCO occupation. Estimates were made for all two-digit occupations, with the exception of army occupations (ISCO 0 ).

At the country level, we use the following indicators.

- The percentage of higher educated (ISCED 5 and 6) among full-time working male employees (based on PIAAC). This variable ranges from 15 per cent in Italy to 55 per cent in Japan.

- The reliability of educational credentials. This is defined as the correlation between an individual's years of schooling and numeracy proficiency level at the country level. This correlation ranges from 0.37 in Cyprus to 0.56 in Belgium.

- The EPL index (OECD, 2012a). This variable measures the extent of labour market regulation based on a number of indicators related to the strictness of regulations on dismissals and temporary contracts. It has a range of 0.26 in the United States to 2.92 in the Czech Republic. ${ }^{5}$

- The coverage rate. This variable is defined ${ }^{6}$ as the number of employees covered by a collective agreement, divided by the total number of wage and salary earners in a country, based on the OECD (2012b). The variable has a range of 13.6 per cent in the United States to 99 per cent in Austria.

The resulting data set includes 22 countries and 32,420 individuals. To avoid outliers in the distribution of skill proficiency per country-specific ISCO two-digit category, we omit the first and 99th percentiles of respondents in each occupation per country. This leaves us with a working sample of 29,550 individuals.

\section{Model}

As outlined in the introduction, from a human capital perspective we expect the college wage premium to be driven by skills. So, we expect the following.

H1: The college wage premium is partly explained by the higher proficiency in the key information skills of higher-educated workers compared to medium-educated workers.

However, this is not sufficient. Skills can only have an effect on worker productivity if they are actually used at work. The concept of proficient skill use captures this idea,

${ }^{5}$ See http://www.oecd.org/employment/emp/EPL-timeseries.xlsx.

${ }^{6}$ See http://stats.oecd.org/glossary/detail.asp?ID=3554. 
since it is defined as the multiplicative effect of skill proficiency and skill use (van der Velden and Bijlsma, 2015). It reflects the idea that productivity is highest when workers have a high proficiency level and use these skills more intensely. We therefore propose the following hypothesis.

H2: The college wage premium is partly explained by the greater proficient skill use of key information skills of higher-educated workers compared to medium-educated workers. This effect of proficient skill use is greater than the effect of skill proficiency alone.

However, the college wage premium is only partly determined by an individual's skills or proficient skill use. Research on over- and undereducation shows that wages are determined not only by actual years of schooling but also - and even more so - by required years of schooling (Duncan and Hoffman, 1981; Sattinger, 1993, 2012; Groot and Maassen van den Brink, 2000; Hartog, 2000; Allen and van der Velden, 2001; McGuiness, 2006; Quintini, 2011) and that the returns to overschooling are weaker. This argument is best explained by matching theory. Productivity is highest when workers' skills are a good match to the skills that are required in the job. Overskilling is also rewarded, but not fully, since the utilization of these additional skills is restricted by job characteristics. Conversely, underskilling will yield a wage penalty, since these workers will not reach the same productivity level as their co-workers with matching skills. It is therefore important to include measures of skill match and mismatch. We therefore present the following hypothesis.

H3: The college wage premium is partly explained by the better match of higher-educated workers with jobs that require the more proficient skill use of key information skills. This effect of better matching with required proficient skill use is greater than the effect of proficient skill use alone.

In the introduction, we already indicated that there are large differences in the average college wage premium across countries. These could be partially explained by country differences in the skill profiles of the higher educated, their use of skills in the work situation, or country differences in the extent to which graduates can find a matching job in terms of the required proficient skill use. However, as indicated by previous authors, other characteristics could play a role as well. As a first obvious explanation, we expect a country's college wage premium to be dependent on the relative supply of higher educated. This brings us to our next hypothesis.

H4: Country differences in the college wage premium are partly explained by the relative supply of higher-educated workers: the greater the numbers of higher educated, the lower the premium.

An alternative explanation is the signalling value of national diplomas. Some educational systems provide more reliable signals about a student's actual skills than others (van der Velden, 2011). This is reflected in the correlation between years of schooling and skills in a country and the following is hypothesized.

H5: Country differences in the college wage premium are partly explained by the signalling value of diplomas: the college wage premium will be higher in countries where diplomas more strongly signal differences in underlying skills.

Finally, country differences in the college wage premium could be related to labour market institutions. The more strongly the labour market is institutionalized (as reflected 
in the EPL or the coverage rate), the higher the college wage premium, after skills are controlled for, which brings us to our last hypothesis.

H6: Country differences in the college wage premium are partly explained by differences in labour market institutions (indicated by the EPL or coverage rate): the college wage premium, after controlling for skills, is higher in countries with stronger labour market institutions.

We use standard Mincer (1974) wage regressions to assess the effect of college degrees on wages. We use a multilevel model to account for the nested structure, allowing for the clustering of errors at the country level. We estimate the following model:

$$
W_{i c}=a_{c}+b H E_{i c}+c L E_{i c}+d C_{i c}+u_{i c}+v_{c}
$$

where $W_{i c}$ is the natural logarithm of the hourly wages of individual $i$ in country $c, a_{c}$ is a country-specific constant, and $H E_{i c}$ and $L E_{i c}$ are two dummies indicating whether individual $i$ is high educated (ISCED 5 and 6) or low educated (ISCED 1 and 2). The reference category comprises the medium educated (ISCED 3 and 4). The term $C_{i c}$ is a vector of control variables (with only two variables, age and age squared) and $u_{i c}$ and $v_{c}$ are idiosyncratic error terms at the individual and country level, respectively. In the next model, we include the numeracy proficiency level $S_{i c}$ :

$$
W_{i c}=a_{c}+b H E_{i c}+c L E_{i c}+d S_{i c}+e C_{i c}+u_{i c}+v_{c} .
$$

A comparison between the college wage premiums denoted by parameters $b$ in equations (1) and (2) shows how it is reduced when we control for numeracy skills. In a human capital framework, we can assume that this numeracy skill proficiency level can only account for the college wage premium if these skills are actually used. That is why our next model includes the concept of proficient skill use. We estimate the following model, where $P S U_{i c}$ is proficient skill use:

$$
W_{i c}=a_{c}+b H E_{i c}+c L E_{i c}+d P S U_{i c}+e C_{i c}+u_{i c}+v_{c} .
$$

Of course, higher skills and the use of these skills should only matter if these skills and their use are actually required in the job. Skills that are not required on the job should have a lower premium and the same would hold for their use:

$$
W_{i c}=a_{c}+b H E_{i c}+c L E_{i c}+d S M_{i c}+e C_{i c}+u_{i c}+v_{c}
$$

where $S M_{i c}$ is a vector of skill match variables, including the five (mis)match variables developed by van der Velden and Bijlsma (2015) and described in section II.

As a robustness check, we also estimate equations (1) to (4) using the percentile rank in the country-specific wage distribution as the dependent variable. This is to check whether, in certain countries with a compressed wage distribution, the models fit better if we use the rank score rather than the logarithm of wages. The conclusions remain qualitatively the same. ${ }^{7}$

We continue the analysis by estimating equation (4) separately for low-, medium-, and high-educated workers. Next, we test a model in which we assess whether the college wage premium differs between those working in the public sector and those working

7 Results available upon request. 
in the private sector, by estimating equations (1)-(4) separately for public- and privatesector workers, respectively.

Finally, we run the analyses separately for each country and relate the college wage premium from equations (1)-(4) to a number of country characteristics. These analyses indicate whether certain country characteristics can explain the cross-country variation in the college wage premium, both with and without controls for the skills, proficient skill use, and skill (mis)match variables. We report only the results for equation (4) (controlling for country differences in skills, proficient skill use, and skill (mis)match variables). ${ }^{8}$

\section{Results}

Table 1 displays the results from equations (1)-(4).

The first column of Table 1 indicates the average college wage premium in the PIAAC data. Compared to their peers with a medium level of education (ISCED 3 and 4), fulltime working male employees with a college degree or above (ISCED 5 and 6) earn, on average, 28 per cent more. Given that most degrees take 4 years to complete, on average, this corresponds to a 7 per cent increase in wages per additional year of schooling. We also find that the penalty for not having a full upper secondary qualification is 16 per cent. This premium/penalty drops considerably once we control for numeracy skills in model 2. The drop in the wage penalty for the low educated is largest, from 16 to 8 per cent, a drop of 50 per cent, indicating that most of the wage penalty for the low educated is related to low numeracy skills. The drop in the college wage premium is 30 per cent, dropping from 28 to 20 per cent. These findings confirm H1: the college wage premium is indeed partially explained by the higher skill levels of degree holders.

Table 1: College wage premium in different models (equations 1-4)

\begin{tabular}{|c|c|c|c|c|}
\hline Variables & $\begin{array}{c}\text { Model } 1 \\
\text { (Eq. 1) }\end{array}$ & $\begin{array}{c}\text { Model } 2 \\
\text { (Eq. 2) }\end{array}$ & $\begin{array}{c}\text { Model } 3 \\
\text { (Eq. 3) }\end{array}$ & $\begin{array}{c}\text { Model } 4 \\
\text { (Eq. 4) }\end{array}$ \\
\hline Low educated & $\begin{array}{c}-15.819^{* * *} \\
(0.741)\end{array}$ & $\begin{array}{l}-7.892^{* * *} \\
(0.739)\end{array}$ & $\begin{array}{l}-6.742^{* * *} \\
(0.726)\end{array}$ & $\begin{array}{l}-5.755^{* * *} \\
(0.719)\end{array}$ \\
\hline High educated & $\begin{array}{l}28.465^{\star * *} \\
(0.512)\end{array}$ & $\begin{array}{l}19.870^{* * *} \\
(0.532)\end{array}$ & $\begin{array}{l}16.442^{\star * *} \\
(0.537)\end{array}$ & $\begin{array}{l}10.684^{* * *} \\
(0.553)\end{array}$ \\
\hline \multicolumn{5}{|l|}{ Controls } \\
\hline $\begin{array}{l}\text { Age and age squared } \\
\text { Numeracy }\end{array}$ & yes & $\begin{array}{l}\text { yes } \\
\text { yes }\end{array}$ & yes & yes \\
\hline Proficient skill use & & & yes & \\
\hline Skill mismatch variables & & & & yes \\
\hline Number of individuals & 29,552 & 29,552 & 29,552 & 28,974 \\
\hline Number of countries & 22 & 22 & 22 & 22 \\
\hline $\mathrm{BIC}$ & $28,896.1$ & $26,989.1$ & $26,123.4$ & $24,233.7$ \\
\hline \multicolumn{5}{|l|}{ Variance components } \\
\hline Between variance & 0.095 & 0.097 & 0.098 & 0.092 \\
\hline Within variance & 0.155 & 0.145 & 0.141 & 0.134 \\
\hline Total variance & 0.250 & 0.242 & 0.239 & 0.226 \\
\hline
\end{tabular}

Notes: Parameters multiplied by 100 ; standard errors in parentheses; ${ }^{* * *} p<0.01,{ }^{* *} p<0.05,{ }^{*} p<0.1$.

8 The other results are available upon request. 
Model 3 includes proficient skill use instead of the skill level itself. The rationale is that the college wage premium can be a premium for higher skills, but only if these skills are actually used on the job. The concept of proficient skill use takes that into account. We can see that the college wage premium drops further, to 16 per cent, which suggests that 42 per cent of the original college wage premium is related to higher skill levels and their use on the job. We also note a further drop in the wage penalty among the lower educated, to 7 per cent, indicating that 57 per cent of the original wage penalty is related to lower numeracy levels and the lower use of these skills on the job. This confirms H2: the college wage premium is better explained by the proficient skill use of degree holders than by their skill levels alone.

Model 4 includes five skill (mis)match variables developed by van der Velden and Bijlsma (2015). This model controls for the fact that lower and higher educated workers could obtain different returns for proficient skill use depending on whether the skill level or the use of skills is a match or not. We observe a slight further drop in the wage penalty for the lower educated, from 7 to 6 per cent, indicating that 64 per cent of the original wage penalty is related to differences in the returns to matches or mismatches for proficient skill use. More interestingly, we note a strong drop in the college wage premium, to 11 per cent, indicating that 62 per cent of the original college wage premium is related to differences in the returns to matches or mismatches for proficient skill use.

Table 2 shows the estimates of equation (4) separately for low, medium, and higher educated. ${ }^{9}$

Table 2 shows that most of the estimates are highest for the high educated and lower for the low educated. As an illustration, a one standard deviation increase in typically required numeracy skills with typically required use increases wages for the higher educated by 15.5 per cent $\left(=1.036^{*} 1.5 * 10\right) .{ }^{10}$ An equivalent increase in required numeracy skills among the lower educated yields a premium of 10.9 per cent. The wage premium for one standard deviation more skills than required is 9.7 per cent for the higher educated and 6.8 per cent for the low educated. Finally, having one standard deviation fewer skills than are typically required on the job leads to a wage penalty of 10.0 per cent for the high educated and 8.6 per cent for the low educated.

Is the college wage premium different for public-sector and private-sector workers? Table 3 presents the analyses of equations (1)-(4) separately for those working in the public and private sectors.

The results in Table 3 show that the college wage premium is highest in the private sector ( 29.5 per cent vs 24.8 per cent) but the penalty for being low educated is highest in the public sector (20.3 per cent vs 14.4 per cent). Moreover, educational wage effects in the private sector are driven more by the match between required skills and skill use. The college wage premium in the private sector drops from 29.5 to 9.9 per cent in model 4 after including the (mis)match variables, a decrease of 67 per cent. In the public sector, the college wage premium drops from 24.8 per cent in model 1 to 11.3 per cent in model 4, a decrease of 55 per cent. For the lower educated, the drop in the

\footnotetext{
9 As a robustness check, we also estimated equation (4) by field of study (results available upon request). This was done only for the high educated. The results indicate that the returns to required numerical skills do not differ between the different fields of study, such as science and engineering versus social science, business, and law. However, the returns to having higher numerical skills than typically required are highest in the science and engineering sector, as would be expected.

${ }^{10}$ For more information on this calculation, see van der Velden and Bijlsma (2015).
} 
Table 2: Proficient skill use matching model for low, medium, and high educated

\begin{tabular}{lccc}
\hline Variables & $\begin{array}{c}\text { Low educated } \\
\text { (ISCED 1-2) }\end{array}$ & $\begin{array}{c}\text { Medium educated } \\
\text { (ISCED 3-4) }\end{array}$ & $\begin{array}{c}\text { High educated } \\
\text { (ISCED 5-6) }\end{array}$ \\
\hline $\begin{array}{l}\text { Returns to typically required utilization with typically } \\
\text { required skills }\end{array}$ & $\begin{array}{c}0.728^{* * *} \\
(0.043)\end{array}$ & $0.805^{* * *}$ & $\begin{array}{c}1.036^{* * *} \\
(0.022)\end{array}$ \\
$\begin{array}{l}\text { Returns to typically required utilization with higher } \\
\text { skills }\end{array}$ & $0.451^{* * *}$ & $0.578^{* * *}$ & $0.647^{* * *}$ \\
Returns to typically required utilization with lower & $(0.103)$ & $(0.052)$ & $(0.067)$ \\
skills & $-0.572^{* * *}$ & $-0.548^{* * *}$ & $-0.668^{* * *}$ \\
Returns to overutilization with typically required & $(0.090)$ & $(0.050)$ & $(0.055)$ \\
skills & $0.699^{* * *}$ & $0.551^{* * *}$ & $0.662^{* * *}$ \\
Returns to underutilization with typically required & $(0.183)$ & $(0.081)$ & $(0.094)$ \\
skills & -0.168 & $-0.528^{* * *}$ & $-0.479^{* * *}$ \\
Number of individuals & $(0.198)$ & $(0.082)$ & $(0.075)$ \\
Number of countries & 3,742 & 14,574 & 10,658 \\
BIC & 22 & 22 & 22 \\
Variance components & $2,964.6$ & $11,705.6$ & $8,964.4$ \\
Between variance & & & 0.086 \\
Within variance & 0.087 & 0.098 & 0.133 \\
Total variance & 0.123 & 0.129 & 0.219 \\
\hline
\end{tabular}

Notes: Parameters multiplied by 100 ; standard errors in parentheses; ${ }^{* \star *} p<0.01,{ }^{* *} p<0.05,{ }^{*} p<0.1$; controls include age, age squared.

wage penalty compared to medium-educated workers is 72 per cent in the private sector and only 45 per cent in the public sector. It is clear that, within countries, the college wage premium is partly driven by institutional factors when a worker is employed in the public sector. ${ }^{11}$

How is the college wage premium related to country characteristics? Are college wage premiums lower in countries where the relative supply of higher educated workers is low, even after controlling for the differences in skills, skill use, and (mis)matching? And is it lower in countries where educational credentials are only a weak signal for underlying skills? Or is the college wage premium related more to institutional characteristics, such as the EPL or coverage rate? Figures 1-4 present some descriptive information. ${ }^{12}$

Figure 1 plots the college wage premium against the percentage of higher educated in the labour force of male full-time working employees. This percentage varies from 15 per cent in Italy to 55 per cent in Japan. Figure 1 shows a clear negative relation. The results indicate that the college wage premium, net of skills, the use of these skills, or the returns of being in a job where these skills are or are not required, is negatively related to the relative supply of higher educated workers. These results confirm H4 and are in line with previous results that show a negative relation between changes in

11 The selection into the private or public sector is not random and may depend on skills as well. To check this, we ran a separate analysis in which we regressed the education dummies and the skills plus control variables on the odds to entering the public sector. There is no effect of skills in this regression, indicating that it is unlikely that the selection is based on skills.

12 We only provide figures related to equation (4). The other figures are available upon request. 
Table 3: College wage premium in different models (equations 1-4), separately for public-sector and private-sector workers

\section{Public-sector workers}

\begin{tabular}{|c|c|c|c|c|}
\hline Variables & $\begin{array}{l}\text { Model } 1 \\
\text { (Eq. 1) }\end{array}$ & $\begin{array}{l}\text { Model } 2 \\
\text { (Eq. 2) }\end{array}$ & $\begin{array}{l}\text { Model } 3 \\
\text { (Eq. 3) }\end{array}$ & $\begin{array}{c}\text { Model } 4 \\
\text { (Eq. 4) }\end{array}$ \\
\hline Low educated & $\begin{array}{c}-20.279^{\star * *} \\
(1.762)\end{array}$ & $\begin{array}{c}-12.430 * * * \\
(1.760)\end{array}$ & $\begin{array}{c}-12.469^{* * *} \\
(1.736)\end{array}$ & $\begin{array}{c}-11.161^{\star \star *} \\
(1.719)\end{array}$ \\
\hline High educated & $\begin{array}{l}24.834^{* * *} \\
(0.976)\end{array}$ & $\begin{array}{l}17.389^{* * *} \\
(1.024)\end{array}$ & $\begin{array}{l}15.580^{* * *} \\
(1.033)\end{array}$ & $\begin{array}{l}11.280^{* * *} \\
(1.058)\end{array}$ \\
\hline \multicolumn{5}{|l|}{ Controls } \\
\hline $\begin{array}{l}\text { Age and age squared } \\
\text { Numeracy }\end{array}$ & yes & $\begin{array}{l}\text { yes } \\
\text { yes }\end{array}$ & yes & yes \\
\hline Proficient skill use & & & yes & \\
\hline Skill mismatch variables & & & & yes \\
\hline Number of individuals & 6,125 & 6,125 & 6,125 & 6,041 \\
\hline Number of countries & 22 & 22 & 22 & 22 \\
\hline $\mathrm{BIC}$ & $4,689.4$ & $4,342.6$ & $4,248.7$ & $3,963.3$ \\
\hline \multicolumn{5}{|l|}{ Variance components } \\
\hline Between variance & 0.107 & 0.109 & 0.112 & 0.113 \\
\hline Within variance & 0.122 & 0.115 & 0.114 & 0.109 \\
\hline Total variance & 0.229 & 0.226 & 0.226 & 0.222 \\
\hline
\end{tabular}

Notes: Parameters multiplied by 100 ; standard errors in parentheses; ${ }^{* *} p<0.01,{ }^{* *} p<0.05,{ }^{*} p<0.1$.

Private-sector workers

\begin{tabular}{|c|c|c|c|c|}
\hline Variables & $\begin{array}{l}\text { Model } 1 \\
\text { (Eq. 1) }\end{array}$ & $\begin{array}{l}\text { Model } 2 \\
\text { (Eq. 2) }\end{array}$ & $\begin{array}{l}\text { Model } 3 \\
\text { (Eq. 3) }\end{array}$ & $\begin{array}{c}\text { Model } 4 \\
\text { (Eq. 4) }\end{array}$ \\
\hline Low educated & $\begin{array}{c}-14.406^{\star * *} \\
(0.814)\end{array}$ & $\begin{array}{l}-6.493^{* * *} \\
(0.811)\end{array}$ & $\begin{array}{l}-4.915^{\star * *} \\
(0.797)\end{array}$ & $\begin{array}{l}-3.991^{* * *} \\
(0.788)\end{array}$ \\
\hline High educated & $\begin{array}{l}29.491^{* * *} \\
(0.602)\end{array}$ & $\begin{array}{l}20.721^{* * *} \\
(0.622)\end{array}$ & $\begin{array}{l}16.218^{* * *} \\
(0.631)\end{array}$ & $\begin{array}{l}9.878^{* * *} \\
(0.652)\end{array}$ \\
\hline \multicolumn{5}{|l|}{ Controls } \\
\hline Age and age squared & yes & yes & yes & yes \\
\hline Numeracy & & yes & & \\
\hline Proficient skill use & & & yes & \\
\hline Skill mismatch variables & & & & yes \\
\hline Number of individuals & 23,427 & 23,427 & 23,427 & 22,933 \\
\hline Number of countries & 22 & 22 & 22 & 22 \\
\hline $\mathrm{BIC}$ & $23,648.3$ & $22,096.4$ & $21,288.1$ & $19,716.0$ \\
\hline \multicolumn{5}{|l|}{ Variance components } \\
\hline Between variance & 0.096 & 0.097 & 0.098 & 0.089 \\
\hline Within variance & 0.159 & 0.149 & 0.144 & 0.137 \\
\hline Total variance & 0.265 & 0.246 & 0.242 & 0.226 \\
\hline
\end{tabular}

Notes: Parameters multiplied by 100 ; standard errors in parentheses; ${ }^{* *} p<0.01,{ }^{* *} p<0.05,{ }^{*} p<0.1$.

the relative supply of the higher educated and changes in the college wage premium (Walker and Zhu, 2008; Crivellaro, 2014).

Figure 2 plots the college wage premium against the extent to which educational credentials provide a strong signal about the underlying skills. This is simply calculated as the correlation between years of schooling and the numeracy test scores in each country. This correlation varies between a low of 0.37 in Cyprus to a high of 0.56 in Belgium. 
Figure 1: College wage premium per country plotted against the percentage higher educated

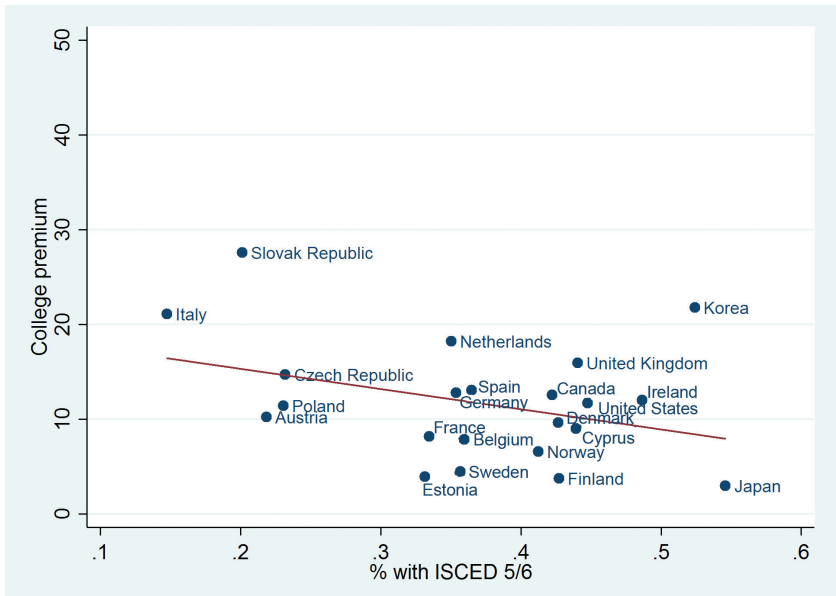

Notes: Based on equation 4 (with controls for age, age squared, proficient skill use plus skill (mis)match): $R^{2}=13.0 \%$.

Figure 2: College wage premium per country plotted against the reliability of the educational credential

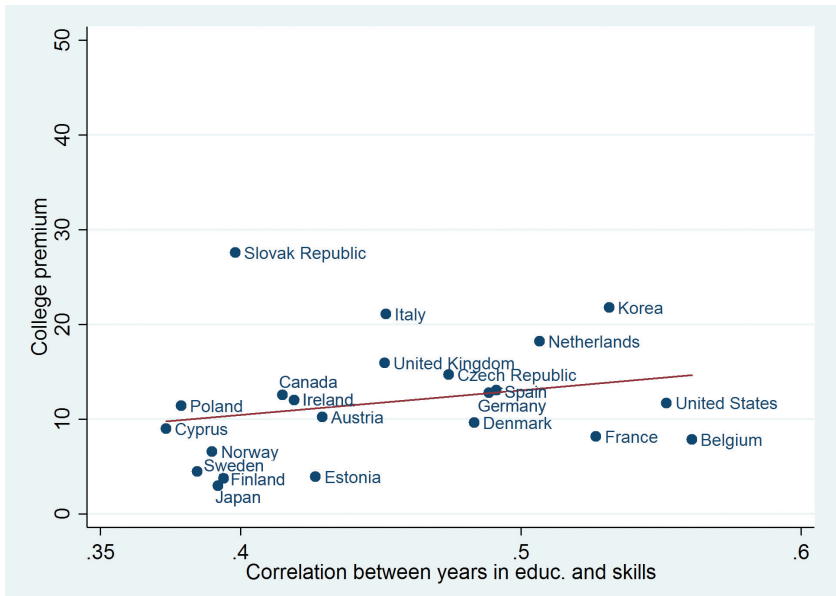

Notes: Based on equation 4 (with controls for age, age squared, proficient skill use plus skill (mis)match): $R^{2}=6.0 \%$.

We observe a weak positive relation (especially when omitting the Slovak Republic), indicating that the college wage premium is indeed positively related to the extent to which higher education credentials signal higher skill levels, as hypothesized in H5. Note that this is true even after controlling for these skills at the individual level. This indicates that graduates profit from a strong signal of their skills, even if they do not possess these skills themselves.

It is important to note that the reliability of educational credentials is not at all related to the relative supply of higher educated workers. This is shown in Figure 3, 
which plots the reliability of educational credentials against the percentage of higher educated in the relevant workforce. We note countries with similar relative supplies of higher educated and vastly different signals about the underlying skills (e.g. Japan vs Korea, Finland vs United States, or Sweden vs Belgium). This is a relevant conclusion, since it means that the expansion of higher education does not imply a blurred relation between years of schooling and skills.

Figure 4 plots college wage premiums against the extent to which labour market institutions dominate the labour market, as indicated by the EPL. This index indicated the strictness of regulations on dismissals and temporary contracts and ranges from a low

Figure 3: Percentage higher educated plotted against the reliability of the educational credential

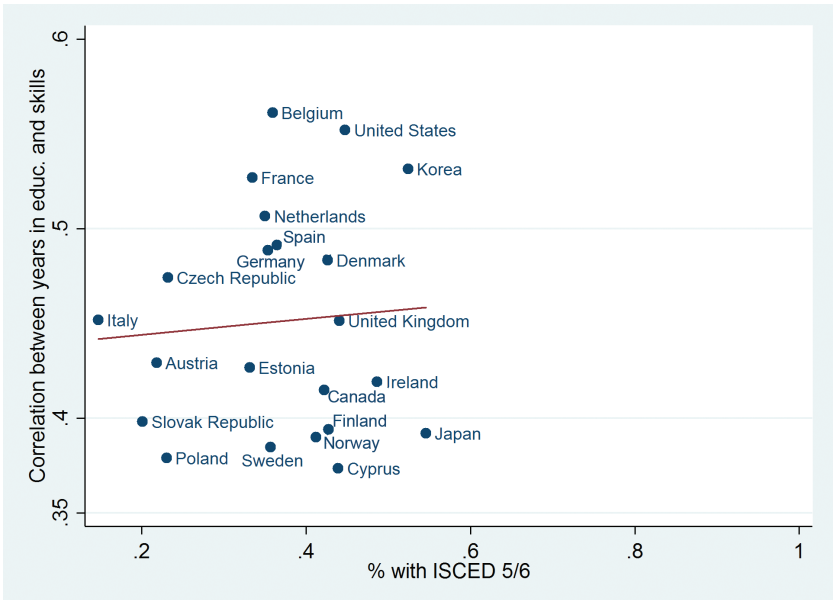

Note: $\mathrm{R}^{2}=0.5 \%$.

Figure 4: College wage premium per country plotted against the EPL

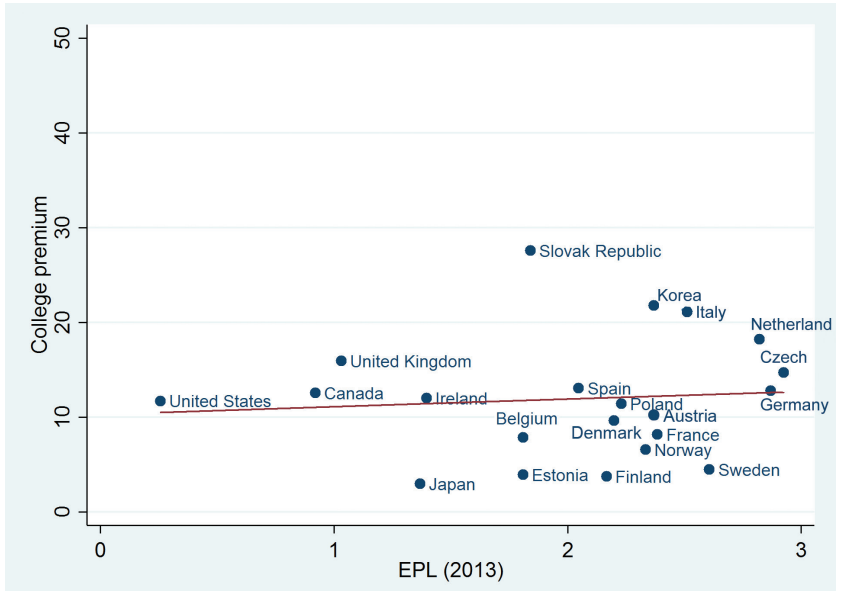

Notes: Based on equation 4 (with controls for age, age squared, proficient skill use plus skill (mis)match): $\mathrm{R}^{2}=0.8 \%$. 
Figure 5: College wage premium per country plotted against the coverage rate

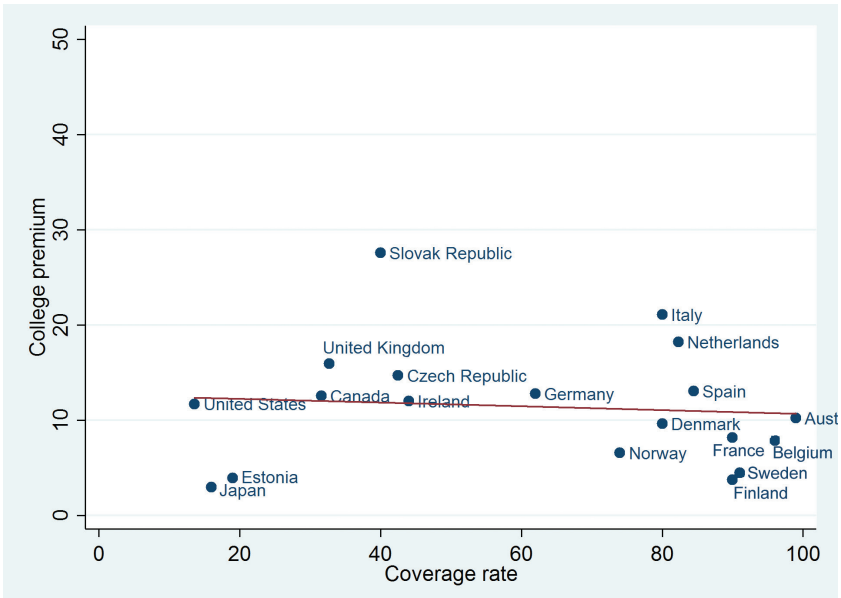

Notes: Based on equation 4 (with controls for age, age squared, proficient skill use plus skill (mis)match): $\mathrm{R}^{2}=0.9 \%$

of 0.26 in the United States to a high of 2.92 in the Czech Republic. The figure clearly shows no relation whatsoever between a country's college wage premium and the EPL. This is true, regardless of whether or not we control for skills, proficient skill use, or (mis)matching in proficient skill use.

We repeat the same analysis, now using a different indicator of labour market institutions: the coverage rate (Figure 5). This coverage rate is the proportion of employees covered by a collective labour agreement and ranges from 13.6 per cent in the United States to 99 per cent in Austria. The results indicate no relation between the coverage rate and the college wage premium after controlling for skills, proficient skill use, or (mis)matching in proficient skill use.

\section{Conclusions}

Workers with a college degree earn substantially more than workers who have no such degree. Using recent data from 22 OECD countries, we estimate this college wage premium to be 28 per cent for male full-time working employees, on average, ranging from 18 per cent in Sweden to 50 per cent in the Slovak Republic. We used PIAAC data to assess whether, within countries, this college wage premium is related to differences in the skills profiles of graduates, the use of these skills, or to differences in the returns to skills when workers hold jobs that match their skills and skill-use level. Moreover, we used these data to determine whether the cross-country variation in these premiums is related to the relative supply of higher-educated workers, the reliability of educational credentials, and labour market institutions, such as the EPL or the coverage rate.

The results show that the college wage premium is indeed partly explained by the higher skill levels of graduates from higher education; however, this is only part of the story. College degree holders also receive higher wages, because they are more often 
able to use these skills in the jobs they hold. If we further control for job requirements in terms of skill proficiency and skill use, we note that two-thirds of the original college wage premium is related to skill, skill use, and the match with the requirements of the job. This effect is stronger for workers in the private sector, where the college wage premium drops by 72 per cent after controlling for these factors. For workers in the public sector, this drop in the college wage premium is 45 per cent.

The results largely favour a human capital interpretation of the college wage premium. Higher-educated graduates earn more than medium-educated graduates because they have higher skill levels and are working in jobs where they can use these skills more often and where these skills are actually required. However, this holds more for the private sector than for the public sector, indicating that, at least in the public sector, the college wage premium is to some extent driven by institutional factors rather than being a premium for higher skills, skill use, or skill requirements.

We find no effect of labour market institutions (EPL or coverage rate) on the crosscountry differences in the college wage premium. This result is in line with the findings of Crivellaro (2014). The cross-country variation in the college wage premium is, however, related to the relative supply of higher-educated workers. As shown in previous research, changes in the relative supply drive changes in the college wage premium within countries (Goldin and Katz, 2007; Walker and Zhu, 2008; Crivellaro, 2014). Controlling for skills, skill use, and matching with job requirements in these areas, we also find a negative relation between a country's relative supply of graduates and the college wage premium. This means that policy-makers and prospective students must be aware that expansion of the higher education system will have a negative effect on returns to higher education degrees.

We also find evidence that cross-country differences in the college wage premium are related to how strongly educational credentials signal skills (Arrow, 1973, Spence, 1973). The college wage premium is highest in countries where this signal is strong. This is even the case when we control for skills at the individual level, suggesting that this signalling value also increases the wage premium for college-educated workers who lack such skills. It is important to note that the reliability of educational credentials is not at all related to the relative supply of the higher educated. There are countries with similar relative supplies of higher-educated workers and vastly different signals about the underlying skills. The expansion of higher education, therefore, does not automatically imply a blurred relation between years of schooling and skills. This result is important for policy-makers, since the potential negative effect of the expansion of higher education could thus be offset by strengthening the signalling value of diplomas. The relevant implication is that policy-makers aiming to increase enrolment in higher education should make sure that the selection on relevant skills is increased at the same time.

\section{References}

Allen, J., and Bijlsma, I. (2015), 'Skill Profiles of Occupations: Robust Multi-level Estimates Based on PIAAC Data', Maastricht, ROA.

- Van der Velden, R. (2001), 'Educational Mismatches Versus Skill Mismatches: Effects on Wages, Job-related Training, and On-the-job Search', Oxford Economic Papers, 3, 434-52.

Arrow, K. J. (1973), 'Higher Education as a Filter', Journal of Public Economics, 2(3), 193-216. 
Bills, D. (2003), 'Credentials, Signals and Screens: Explaining the Relationship between Schooling and Job Assignment', Review of Educational Research, 73, 441-70.

Collins, R. (1979), The Credential Society: An Historical Sociology of Education and Stratification, New York, Academic Press.

Crivellaro, E. (2014), 'College Wage Premium over Time: Trends in Europe in the Last 15 Years', University of Venice Department of Economics Working Paper 003.

Duncan, G., and Hoffman, S. (1981), 'The Incidence and Wage Effects of Overeducation', Economics of Education Review, 1, 75-86.

European Commission (2013), 'Improving the Quality of Teaching and Learning in Europe's Higher Education Institutions: Report from the High Level Group on the Modernisation of Higher Education', Brussels, European Commission

Freeman, R. (1976), The Overeducated American, New York, Academic Press.

Goldin, C., and Katz, L. (2007), 'The Race between Education and Technology: The Evolution of US Educational Wage Differentials, 1890 to 2005', NBER Working Paper Series 12984.

Grogger, J., and Eide, E. (1995), 'Changes in College Skills and the Rise in the College Wage Premium', The Journal of Human Resources, 30(2), 280-310.

Groot, W., and Maassen van den Brink, H. (2000), 'Overeducation in the Labour Market: A Metaanalysis', Economics of Education Review, 19(2), 149-58.

Hanushek, E., Schwerdt, G., Wiederhold, S., and Woessmann, L. (2015), 'Returns to Skills around the World: Evidence from PIAAC', European Economic Review, 73, 103-30.

Hartog, J. (2000), 'Overeducation and Earnings: Where are We, Where Should We Go?', Economics of Education Review, 19, 131-47.

James, J. (2011), 'The College Wage Premium', Economic Commentary, Federal Reserve Bank of Cleveland.

Katz, L., and Murphy, K. (1992), 'Changes in Relative Wages, 1963-87: Supply and Demand Factors', Quarterly Journal of Economics, 107, 35-78.

Levels, M., Van der Velden, R., and Allen, J. (2014), 'Educational Mismatches and Skills: New Empirical Tests of Old Hypotheses', Oxford Economic Papers, 66(4), 959-82.

McGuiness, S. (2006), 'Overeducation in the Labour Market', Journal of Economic Surveys, 20(3), 387-418.

Mincer, J. (1974), Schooling, Experience, and Earnings, New York, NBER Press.

OECD (2012a), Employment Protection Legislation Index, Paris, OECD Publishing.

- (2012b), 'Trade Union Density and Collective Bargaining Coverage, 1990 and Latest Year', in OECD Employment Outlook 2012, Paris, OECD Publishing.

- (2013a), Skills Outlook: First Results from the OECD Survey of Adult Skills (Volume 1), Paris, OECD Publishing.

- (2013b), Technical Report of the OECD Survey of Adult Skills (PIAAC), Paris, OECD Publishing.

- (2015), Skills Outlook 2015: Youth, Skills and Employability, Paris, OECD Publishing.

Quintini, G. (2011), 'Over-qualified or Under-skilled: A Review of Existing Literature', OECD Social, Employment and Migration Working Papers 121, Paris, OECD Publishing.

Sattinger, M. (1993), 'Assignment Models of the Distribution of Earnings', Journal of Economic Literature, 31, 851-80.

- (2012), 'Qualitative Mismatches, Foundations and Trends', Microeconomics, 8, 1-168.

Spence, M. (1973), 'Job Market Signalling', Quarterly Journal of Economics, 87(1), 355-74.

Thurow, L. (1975), Generating Inequality, London, Macmillan.

Van der Velden, R. (2011), 'De effecten van betrouwbaarheid van onderwijsdiploma's op arbeidsproductiviteit: toepassing van een simulatiemodel' [The effects of reliability of educational credentials: application of a simulation model], in J. Dronkers (ed.), Goede bedoelingen in het onderwijs: Kansen en missers, 27-49.

- Bijlsma, I. (2015), 'Skill, Skill Use and Wages: A New Theoretical Perspective', paper for the 2nd PIAAC conference, 22-24 November, Haarlem.

Walker, I., and Zhu, Y. (2008), 'The College Wage Premium and the Expansion of Higher Education in the UK', Scandinavian Journal of Economics, 110(4), 695-709. 